\title{
Response of silage intake and milk production to replacement of barley by barley fibre derived from integrated starch-ethanol process
}

\author{
PEKKA HUHTANEN, HANNELE ALA-SEPPÄLÄ and MATTI NÄSI \\ Department of Animal Husbandry, University of Helsinki \\ SF-00710 Helsinki, Finland
}

\begin{abstract}
A duplicated $4 \times 4$ Latin Square experiment was conducted to determine the effects of a gradually increased level of barley fibre in the diet on ad libitum grass silage intake and milk production. Barley fibre is a fibrous ethanol-starch by-product ( $120 \mathrm{~g}$ crude protein, $550 \mathrm{~g}$ neutral detergent fibre (NDF) and $120 \mathrm{~g} \mathrm{starch} / \mathrm{kg}$ dry matter (DM)). The four supplements, given at the rate of $6.5 \mathrm{~kg} / \mathrm{d}$ on DM basis, were barley (B) and barley of which 333 $\mathrm{g} / \mathrm{kg}$ (BF), $667 \mathrm{~g} / \mathrm{kg}$ (FB) and $1000 \mathrm{~g} / \mathrm{kg}$ (F) were replaced by barley fibre. In addition the cows were given $1 \mathrm{~kg}$ of rapeseed meal and $0.25 \mathrm{~kg}$ of mineral mixture.

As the proportion of barley fibre in the diet increased there was a linear $(\mathrm{P}<0.001)$ increase in silage DM intake. The cows ate less concentrate at the higher levels of barley fibre inclusion, so that there was a tendency for higher total DM intake only when the intermediate levels of barley fibre (diets $\mathrm{BF}$ and $\mathrm{FB}$ ) were given (quadratic effect; $\mathrm{P}<0.1$ ).

Milk yield and fat corrected milk yield were not significantly affected by the level of barley fibre. However, as the proportion of barley fibre in the diet was increased, milk protein content decreased (linear effect; $\mathrm{P}<0.01$ ), there was a trend towards lower milk fat content (linear and quadratic effect; $\mathrm{P}<0.1)$ and milk protein yield decreased $(\mathrm{P}<0.05)$. At the same time the digestibility of organic matter $(\mathrm{OM})$ decreased from 0.742 to $0.661(\mathrm{P}<0.001)$. Digestibilities of ether extract and nitrogen were not affected by the diet but digestibilities of cell wall components decreased with the level of barley fibre. Calculations of energy balance suggested that the metabolizable energy of barley was either utilized less efficiently for milk production or, more likely, cows given barley partitioned more energy to body fat stores than those given barley fibre.
\end{abstract}

Index words: barley, barley fibre, silage, milk production

\section{Introduction}

Traditionally, Finnish dairy concentrates have been based on cereal grains. Although the energy value of barley is high, it has some nutritional shortcomings arising mainly from its suppressive effect on silage intake (CASTLE 1982). To avoid this problem there has been 
Table 1. Composition of experimental diets.

\begin{tabular}{lcccr}
\hline & \multicolumn{4}{c}{ Treatment } \\
\cline { 2 - 5 } & B & BF & FB & F \\
\hline Grass silage & ad lib & ad lib & ad lib & ad lib \\
Rapeseed meal (kg/d) & 1.00 & 1.00 & 1.00 & 1.00 \\
Concentrate (kg DM) & & & & \\
$\quad$ Barley & 6.50 & 4.36 & 2.15 & - \\
$\quad$ Fibre & - & 2.15 & 4.36 & 6.50 \\
Minerals' & $(\mathrm{kg} / \mathrm{d})$ & 0.25 & 0.25 & 0.25 \\
\hline
\end{tabular}

' In mineral mixture (g/kg): Ca 170, P $80, \mathrm{Na} 60, \mathrm{Mg} 80$

interest in replacing barley by fibrous byproducts. At high level of concentrate inclusion, cows given fibrous concentrate have been found to consume more forage than those given starchy concentrates (Tномаs et al. 1986, Sutton et al. 1987, Phipps et al. 1987). However, at lower level of supplementation (ca. $400 \mathrm{~g} / \mathrm{kg} \mathrm{DM}$ ) no differences in silage intake have been observed between barley and sugar beet pulp (CASTLE et al. 1981. Huhtanen 1987 a).

At present, sugar beet pulp and wheat bran are the most important by-products incorporated in dairy concentrates in Finland, but new fibrous by-products from integrated starchethanol production from barley are becoming available. These products, consisting mostly of the cell walls of the endosperm, are produced by a process corresponding to the wet milling of maize, as described in detail by NÄsı (1988). Production started in 1987 and is expected to climb to 35 million $\mathrm{kg}$ in the next few years. The objectives of the present study were to compare the effects of barley fibre, relative to barley, on feed intake, milk production and diet digestibility.

\section{Materials and methods}

\section{Animals and management}

The experiment was conducted with eight lactating Finnish Ayrshire cows. Four of the cows were in their second of fifth lactation and four were heifers. The multiparous cows had calved 43 days (SE 2) and the heifers 103 days (SE 13) before the start of the experiment. The animals were fed and housed individually and had free access to water. Silage was given ad libitum and concentrates were given at 5 and $14 \mathrm{~h}$. Feed refusals were removed and weighed after the morning feeding.

\section{Design and treatments}

The experimental design was a duplicated $4 \times 4$ Latin Square with eight animals, four treatments and four three-week experimental periods. The heifers and the multiparous cows were allocated to separate squares. The four treatments consisted of grass silage ad libitum, $1 \mathrm{~kg}$ of rapeseed meal (RSM), $0.25 \mathrm{~kg}$ of mineral mixture and one of the supplementary feeds. The basal supplement was barley (B), which in three treatments was replaced by 333 $\mathrm{g} / \mathrm{kg}$ (BF), $667 \mathrm{~g} / \mathrm{kg}$ (FB) and $1000 \mathrm{~g} / \mathrm{kg}$ (F) barley fibre (Table 1). RSM was treated to reduce the ruminal degradability (Öljynpuristamo Oy, Helsinki). All the supplements were given at the rate of $6.5 \mathrm{~kg} / \mathrm{d}$ on dry matter (DM) basis. The ingredients of the concentrate mixture were weighed separately and mixed before feeding. Direct-cut silage was made from timothy-meadow fescue sward, harvested with a precision-chop forage harvester and ensiled with a formic acid additive (5 $1 / \mathrm{t})$.

Feed intake and milk yield were recorded daily. Milk has taken for analysis at morning 
Table 2. Chemical composition of experimental feeds $(\mathrm{g} / \mathrm{kg} \mathrm{DM})$ and estimated feed values.

\begin{tabular}{lcccc}
\hline & Silage & Barley & Fibre & Rapeseed meal \\
\hline Dry matter $(\mathrm{g} / \mathrm{kg})$ & 210 & 872 & 936 & 888 \\
In dry matter & & & & 75 \\
Ash & 74 & 23 & 104 & 353 \\
Crude protein & 152 & 137 & 118 & 93 \\
Ether extract & 53 & 37 & 78 & 129 \\
Crude fibre & 312 & 45 & 158 & 349 \\
NFE' & 409 & 758 & 542 & 239 \\
NDF & 560 & 179 & 556 & 169 \\
ADF & 324 & 37 & 19 & 70 \\
ADL & 13 & 2 & 132 & 97 \\
Cellulose & 311 & 35 & 406 & 72 \\
Hemicellulose & 236 & 142 & 119 & nd. \\
Starch & nd. & 551 & & 1.027 \\
Feed values & & & 0.909 & 12.27 \\
FFU ${ }^{2} / \mathrm{kg} \mathrm{DM}$ & 0.706 & 13.184 & 10.85 & 293 \\
ME MJ/kg DM & 9.95 & 103 & 90 & \\
DCP & 104 & & & \\
\hline
\end{tabular}

nd. $=$ not determined, ${ }^{\prime} \mathrm{NFE}=$ nitrogen free extracts, ${ }^{2} \mathrm{FFU}=$ fattening feed unit $=0.7 \mathrm{~kg}$ starch, ${ }^{3} \mathrm{DCP}=$ digestible crude protein. In silage: $\mathrm{pH} 3.88$; in dry matter $(\mathrm{g} / \mathrm{kg})$ : sugars 23, lactic acid 41, acetic acid 19, propionic acid 1.0, butyric acid 0.6 ; in total nitrogen $(\mathrm{g} / \mathrm{kg}): \mathrm{NH}_{3}-\mathrm{N} 49$, soluble $\mathrm{N} 548$; D-value 0.622 .

and evening milking on days 16 and 17 of each experimental period and bulked to provide a sample. Live weights were determined at the beginning of the experimental and on days 6 , 7,20 and 21.

Apparent digestibility of the diets was determined using acid-insoluble ash (AIA) as a natural maker ( $V_{\text {AN KeULEN and Young }}$ 1977). Faecal grab samples were taken during the last 5 days of each period at 7 and $16 \mathrm{~h}$.

\section{Chemical analyses}

Samples of feeds were determined for DM by drying at $103^{\circ} \mathrm{C}$, and for organic matter $(\mathrm{OM})$ by ashing at $550^{\circ} \mathrm{C}$. Feed analyses were made according to standard procedures. Silage DM content was corrected for volatile losses of lactic acid, volatile fatty acids (VFA) and ammonia according to PORTER et al. (1984). OM digestibility of silage was determined by the method of TILley and Terry (1963). Fermentation quality of the silage was determined by methods described by НuнтANEN (1987 a). Other analyses were for neutral detergent fibre (NDF), acid detergent fibre
(ADF) and acid detergent lignin (ADL) according to Goering and VAN Soest (1970), for starch by polarimetric method and for AIA according to VAN Keulen and Young (1977). Feed values (feed units $=$ FFU, digest ible crude protein $=$ DCP) were calculated according to Finnish Feed Tables (SALo et al. 1982) and metabolizable energy according to the Ministry of Agriculture, Fisheries and Food (MAFF 1975). Digestibility coefficients for barley fibre determined in sheep were obtained from NÃsı (1988). Chemical composition of experimental feeds and estimated feeding values are presented in Table 2 .

Milk fat and protein contents were analysed with an infrared milk analyser.

\section{Energy utilization}

The energy requirements for maintenance were calculated according to the Agricultural Research Council (ARC 1980) and the requirements for live weight change according to MAFF (1975). Milk energy was calculated from equations of TYRREL and REID (1965). $\mathrm{ME}$ intake was estimated from digestible $\mathrm{OM}$ 
Table 3. Feed intake (kg DM/d) and estimated nutrient consumption in cows given grass silage ad libitum with increasing levels of barley fibre.

\begin{tabular}{|c|c|c|c|c|c|c|c|}
\hline & \multicolumn{4}{|c|}{ Treatment } & \multirow[t]{2}{*}{$\begin{array}{l}\text { SEM } \\
18 \mathrm{df}\end{array}$} & \multicolumn{2}{|c|}{$\begin{array}{c}\text { Statistical } \\
\text { significance } \\
\text { of effect } \\
\end{array}$} \\
\hline & B & $\mathrm{BF}$ & FB & $\mathrm{F}$ & & L & Q \\
\hline Grass silage & 9.91 & 10.56 & 11.25 & 11.56 & 0.23 & $* * *$ & NS \\
\hline Barley & 6.47 & 4.29 & 2.09 & - & 0.05 & - & - \\
\hline Fibre & - & 2.13 & 3.97 & 5.10 & 0.29 & - & - \\
\hline Rapeseed meal & 0.88 & 0.87 & 0.82 & 0.71 & 0.04 & - & - \\
\hline Concentrate total & 7.35 & 7.29 & 6.87 & 5.82 & 0.34 & $* *$ & NS \\
\hline Total DM intake & 17.26 & 17.86 & 18.12 & 17.38 & 0.35 & NS & NS \\
\hline $\begin{array}{l}\text { DM intake as \% } \\
\text { of live weight }\end{array}$ & 3.12 & 3.27 & 3.31 & 3.15 & 0.06 & NS & $*$ \\
\hline $\begin{array}{l}\text { DM intake as } \\
\mathrm{g} / \mathrm{kg} \mathrm{W} W^{0.75}\end{array}$ & 151.2 & 157.9 & 159.9 & 152.5 & 3.04 & NS & $*$ \\
\hline $\mathrm{FFU} / \mathrm{d}$ & 15.55 & 15.36 & 14.86 & 13.53 & 0.31 & $* * *$ & NS \\
\hline $\mathrm{ME} \mathrm{MJ/d}$ & 198.8 & 198.2 & 194.0 & 179.1 & 3.72 & $* *$ & NS \\
\hline DCP $\mathrm{g} / \mathrm{d}$ & 1955 & 1989 & 1984 & 1874 & 38.9 & NS & NS \\
\hline
\end{tabular}

SEM = standard error of means

Significance: NS (non-significant), ${ }^{*}(\mathrm{P}<0.05),{ }^{* *}(\mathrm{P}<0.01),{ }^{* * *}(\mathrm{P}<0.001)$

$\mathrm{L}, \mathrm{Q}=$ linear and quadratic effect of the level of barley fibre

(DOM) as described by Huhtanen (1987 a) and according to MAFF (1975).

\section{Statistical analyses}

Statistical analyses were based on the results for the last 7 days of each period except for live weight and live change. The model used to analyse the data was

$y_{i j k m}=S_{i}+C_{j}\left(S_{j}\right)+P_{k}+T_{i}+e_{i j k m,}$,

where $S, C, P$ and $T$ represent square, cow, period and treatment effects. The sums of squares for treatment effects were further partitioned using polynomial contrast into linear, quadratic and cubic effects of the level of barley fibre in the diet (SNEDECOR and Cochran 1967).

\section{Results}

\section{Feed intake}

Replacement of barley with gradually increasing levels of barley fibre led to a linear increase $(\mathrm{P}<0.001)$ in silage DM intake (Table 3). At the same time, however, the cows ate less concentrate mixture, SO that the total DM intake was not significantly affected. There were large individual differences between the animals in the intake of the supplements with the two highest levels of barley fibre. The total DM intake tended, however, to be higher when the intermediate levels (diets $\mathrm{BF}$ and $\mathrm{FB}$ )) of fibre were given (quadratic trend, $\mathrm{P}<0.1$ ), and when expressed in terms of $\mathrm{kg} \mathrm{DM} / 100 \mathrm{~kg}$ live weight the quadratic trend reached statistical significance $(\mathrm{P}<$ 0.05 ). As the proportion of barley fibre increased there was a linear decrease in estimated FFU and ME intakes $(\mathrm{P}<0.001$; $\mathrm{P}<0.01$ ).

Because of the different carbohydrate compositions of barley and barley fibre, there were marked differences in the intake of the various carbohydrates (Table 4). As the proportion of barley fibre in the diet increased, the intake of starch decreased and the intakes of cellulose and especially hemicellulose increased. 
Table 4. Daily intake ( $\mathrm{kg}$ ) of crude protein, ether extract, starch, crude fibre, NFE, NDF, ADF, cellulose and hemicellulose in cows given grass silage ad libitum with increasing levels of barley fibre.

\begin{tabular}{|c|c|c|c|c|c|c|c|}
\hline & \multicolumn{4}{|c|}{ Treatment } & \multirow[t]{2}{*}{$\begin{array}{l}\text { SEM } \\
18 \mathrm{df}\end{array}$} & \multicolumn{2}{|c|}{$\begin{array}{c}\text { Statistical } \\
\text { significance } \\
\text { of effect }\end{array}$} \\
\hline & B & $\mathrm{BF}$ & FB & F & & L & Q \\
\hline Crude protein & 2.71 & 2.76 & 2.76 & 2.62 & 0.05 & NS & NS \\
\hline Ether extract & 0.85 & 0.97 & 1.06 & 1.08 & 0.03 & $* * *$ & NS \\
\hline Starch & 3.56 & 2.61 & 1.62 & 0.60 & 0.05 & $* * *$ & NS \\
\hline Crude fibre & 3.50 & 3.94 & 4.34 & 4.51 & 0.08 & $* * *$ & NS \\
\hline NFE & 9.26 & 9.03 & 8.63 & 7.75 & 0.17 & $* * *$ & NS \\
\hline NDF & 6.91 & 8.08 & 9.07 & 9.48 & 0.18 & $* * *$ & NS \\
\hline $\mathrm{ADF}$ & 3.60 & 4.05 & 4.46 & 4.63 & 0.08 & $* * *$ & NS \\
\hline Cellulose & 3.39 & 3.80 & 4.17 & 4.33 & 0.07 & $* * *$ & NS \\
\hline Hemicellulose & 3.32 & 4.02 & 4.62 & 4.84 & 0.12 & $* * *$ & NS \\
\hline
\end{tabular}

For significance: see Table 3.

Table 5. Milk yield, milk composition and feed conversion in cows given grass silage ad libitum with increasing levels of barley fibre.

\begin{tabular}{|c|c|c|c|c|c|c|c|}
\hline & \multicolumn{4}{|c|}{ Treatment } & \multirow[t]{2}{*}{$\begin{array}{l}\text { SEM } \\
18 \mathrm{df}\end{array}$} & \multicolumn{2}{|c|}{$\begin{array}{l}\text { Statistical } \\
\text { significance } \\
\text { of effect }\end{array}$} \\
\hline & B & $\mathrm{BF}$ & FB & $\mathrm{F}$ & & $\mathbf{L}$ & Q \\
\hline Milk yield (kg/d) & 24.4 & 25.1 & 24.6 & 24.0 & 0.41 & NS & NS \\
\hline FCM yield $(\mathrm{kg} / \mathrm{d})$ & 26.3 & 27.5 & 26.2 & 25.3 & 0.58 & NS & NS \\
\hline Fat yield $(\mathrm{g} / \mathrm{d})$ & 1105 & 1165 & 1089 & 1043 & 31 & NS & NS \\
\hline Protein yield $(\mathrm{g} / \mathrm{d})$ & 771 & 776 & 745 & 731 & 13 & $*$ & NS \\
\hline \multicolumn{8}{|l|}{ Milk composition } \\
\hline Fat $(\mathrm{g} / \mathrm{kg})$ & 45.3 & 46.3 & 44.4 & 43.5 & 0.90 & NS & NS \\
\hline Protein $(\mathrm{g} / \mathrm{kg})$ & 31.9 & 31.3 & 30.5 & 30.6 & 0.28 & ** & NS \\
\hline \multicolumn{8}{|l|}{ Live weight } \\
\hline Mean (kg) & 555 & 550 & 550 & 554 & 2.66 & NS & NS \\
\hline Change (kg/d) & 0.14 & 0.30 & 0.13 & 0.07 & 0.19 & NS & NS \\
\hline \multicolumn{8}{|l|}{ Feed conversion } \\
\hline $\mathrm{FFU} / \mathrm{kg} \mathrm{FCM}^{\prime}$ & 0.417 & 0.382 & 0.392 & 0.356 & 0.02 & NS & NS \\
\hline $\mathrm{kg} \mathrm{DM} / \mathrm{kg} \mathrm{FCM}$ & 0.663 & 0.663 & 0.697 & 0.694 & 0.01 & * & NS \\
\hline $\mathrm{DCP} \mathrm{g} / \mathrm{kg} \mathrm{FCM}^{2}$ & 62.6 & 61.9 & 63.9 & 61.8 & 1.25 & NS & NS \\
\hline
\end{tabular}

I Production feed units; intake corrected for maintenance and live weight change.

2 Production DCP; intake corrected for maintenance. For significance: see Table 3.

\section{Milk yield and milk composition}

There were no significant differences between the treatments in milk yield or $4 \%$-fat corrected milk (FCM) yield (Table 5). Milk protein content decreased linearly $(\mathrm{P}<0.01)$ and there was a tendency (linear effect, $\mathrm{P}<0.07$ ) for lower milk fat content as the proportion of barley fibre increases. Milk pro- tein yield decreased (linear effect, $\mathrm{P}<0.005$ ), but milk fat yield was not significantly affected although there was a tendency for linear $(\mathrm{P}<0.07)$ and quadratic $(\mathrm{P}<0.10)$ effects, with a maximum value being observed when diet $\mathrm{BF}$ was fed and a minimum value when $\operatorname{diet} \mathrm{F}$ was fed. There were no differences between cows and heifers in their response to the dietary treatments and the treatment * square 
term in statistical analyses was small. No significant differences were observed in live weight. Live weight changes were positive for all treatments, but they were variable between the animals and no consistent diet effect was observed.

Feed conversion expressed in terms of production $\mathrm{FFU} / \mathrm{kg} \mathrm{FCM}$ tended to improve as the proportion of barley fibre in the diet increased. However, the amount of DM consumed per kg of FCM, increased lineary at the same time $(\mathrm{P}<0.05)$.

\section{Digestibility}

The digestibility of DM and OM decreased linearly $(\mathrm{P}<0.001)$ as the level of barley fibre increased (Table 6), while the digestibilities of $\mathrm{N}$ and ether extract did not change NDF and ADF digestibilities decreased (linear effect, $\mathrm{P}<0.001$; quadratic effect, $\mathrm{P}<0.05$ ), with the minimum value being observed when diet FB was fed. Likewise, the digestibilities of cellulose and hemicellulose decreased with the level of barley fibre (linear effect, $\mathrm{P}<0.01$ ). The digestibility of barley fibre calculated as a difference averaged 0.669 (SE 0.021) and was not significantly affected by the level of barley fibre.

\section{Energy balance}

In spite of the slightly higher OM intake when diets $\mathrm{BF}$ and $\mathrm{FB}$ were fed (Table 7), DOM and estimated ME intakes decreased as the proportion of barley fibre in the diet increased (linear effect, $\mathrm{P}<0.001$ ). Milk energy output tended to decrease (linear effect, $\mathrm{P}<0.06$ ), although the reduction was evident only when $\operatorname{diet} \mathrm{F}$ was fed. The efficiency of transferring surplus ME into milk $\left(k_{1}\right)$ improved with the level of barley fibre (linear effect, $\mathrm{P}<0.001$ ) when live weight change was ignored. Including live weight change, the efficiency of utilization of ME averaged 0.628 (SE 0.017) and tended to improve as the proportion of barley fibre increased. The difference did not reach statistical significance because of the wide variation in estimated ME output from live weight change.

\section{Discussion}

The increased silage DM intake with increased level of barley fibre was confounded by the reduced intake of the supplement. However relative to the diet of barley alone, there were increases of 0.60 and $0.86 \mathrm{~kg}$ in the total DM intake when diets $\mathrm{BF}$ and $\mathrm{FB}$ were fed. The reasons for higher feed intakes with diets $\mathrm{BF}$ and $\mathrm{FB}$ are uncertain but may be related to less pronounced post-prandial depression in rumen $\mathrm{pH}$ and more efficient cellulolysis in the rumen. The adverse effects of barley on silage intake have their origin in reduced cellulolytic activity in the rumen (Thomas and Chamberlain 1982). Dietary starch content decreased from 206 to $35 \mathrm{~g} / \mathrm{kg}$ DM as the proportion of barley fibre in the diet increased. Huhtanen (1988), however, did not find any differences between barley and unmolassed sugar beet pulp supplements in their effects on rumen $\mathrm{pH}$ or on the degradation of silage or hay DM when the supplements comprised $520 \mathrm{~g} / \mathrm{kg}$ of the total DM intake.

There is some contradiction in the literature regarding the effect of different carbohydrate supplements on silage intake. THомAs et al. (1986) observed $0.9 \mathrm{~kg}$ higher silage DM intake with a mixture of unmolassed sugar beet pulp and rice bran than with barley based concentrate. PHIPPs et al. (1987) reported $0.5 \mathrm{~kg}$ higher silage DM intake for cows given fibrous concentrates than for those given starchy concentrates. In experiments where the supplement comprised $400-500 \mathrm{~g} / \mathrm{kg}$ of the total DM intake, no differences were found between sugar beet pulp and barley supplements (CAstle et al. 1981, Huhtanen 1987 a). In the present study the supplements comprised from 335 (diet F) to 426 (diet B) g/kg of the total DM intake.

The present results are in agreement with a number of other trials in which starchy and fibrious concentrates had the same effect on 
Table 6. Digestibility of different dietary constituents in cows given grass silage ad libitum with increasing levels of barley fibre.

\begin{tabular}{|c|c|c|c|c|c|c|c|}
\hline & \multicolumn{4}{|c|}{ Treatment } & \multirow[t]{2}{*}{$\begin{array}{l}\text { SEM } \\
18 \mathrm{df}\end{array}$} & \multicolumn{2}{|c|}{$\begin{array}{c}\text { Statistical } \\
\text { significance } \\
\text { of effect }\end{array}$} \\
\hline & B & $\mathrm{BF}$ & FB & $\mathrm{F}$ & & L & Q \\
\hline Dry matter & 0.726 & 0.700 & 0.658 & 0.639 & 0.006 & $* * *$ & NS \\
\hline Organic matter & 0.742 & 0.718 & 0.679 & 0.661 & 0.006 & $* * *$ & NS \\
\hline Crude protein & 0.696 & 0.706 & 0.695 & 0.682 & 0.007 & NS & NS \\
\hline Ether extract & 0.581 & 0.655 & 0.624 & 0.590 & 0.026 & NS & NS \\
\hline Crude carboh. ${ }^{1}$ & 0.763 & 0.726 & 0.680 & 0.663 & 0.006 & $* * *$ & NS \\
\hline NDF & 0.688 & 0.670 & 0.639 & 0.656 & 0.007 & $* * *$ & $*$ \\
\hline $\mathrm{ADF}$ & 0.696 & 0.676 & 0.643 & 0.660 & 0.008 & $* * *$ & * \\
\hline Cellulose & 0.742 & 0.729 & 0.701 & 0.717 & 0.007 & $* *$ & NS \\
\hline Hemicellulose & 0.679 & 0.665 & 0.636 & 0.651 & 0.007 & $* *$ & NS \\
\hline
\end{tabular}

Crude carbohydrates $=$ NFE + crude fibre.

For significance: see Table 3.

Table 7. Calculated energy balance (MJ/day) and efficiency of conversion of surplus to maintenance into milk in cows given grass silage ad libitum with increasing levels of barley fibre.

\begin{tabular}{|c|c|c|c|c|c|c|c|}
\hline & \multicolumn{4}{|c|}{ Treatment } & \multirow[t]{2}{*}{$\begin{array}{l}\text { SEM } \\
18 \mathrm{df}\end{array}$} & \multicolumn{2}{|c|}{$\begin{array}{c}\text { Statistical } \\
\text { significance } \\
\text { of effect }\end{array}$} \\
\hline & B & BF & FB & $\mathrm{F}$ & & L & Q \\
\hline $\mathrm{OM}$ intake $(\mathrm{kg} / \mathrm{d})$ & 16.32 & 16.70 & 16.79 & 15.95 & 0.32 & NS & NS \\
\hline DOM' intake $(\mathrm{kg} / \mathrm{d})$ & 12.15 & 12.01 & 11.40 & 10.57 & 0.26 & $* * *$ & NS \\
\hline DE intake ${ }^{2}$ & 230.8 & 228.1 & 216.6 & 200.9 & 4.91 & $* * *$ & NS \\
\hline $\mathrm{ME}$ intake & 198.5 & 196.2 & 186.2 & 172.7 & 4.23 & $* * *$ & NS \\
\hline $\begin{array}{l}\text { ME from change of } \\
\text { live weight }{ }^{3}\end{array}$ & -5.7 & -11.3 & -4.9 & -2.8 & 6.14 & NS & NS \\
\hline $\begin{array}{l}\text { Energy output } \\
\text { Maintenance } \\
\text { Milk }\end{array}$ & $\begin{array}{l}51.9 \\
80.3\end{array}$ & $\begin{array}{l}51.6 \\
83.3\end{array}$ & $\begin{array}{l}51.6 \\
79.3\end{array}$ & $\begin{array}{l}51.9 \\
76.7\end{array}$ & $\begin{array}{l}0.19 \\
1.61\end{array}$ & $\begin{array}{l}\text { NS } \\
\text { NS }\end{array}$ & $\begin{array}{l}\text { NS } \\
\text { NS }\end{array}$ \\
\hline $\begin{array}{l}\text { Efficiency } \\
\text { Ignoring live } \\
\text { weight change } \\
\text { Including live }\end{array}$ & 0.556 & 0.577 & 0.593 & 0.637 & 0.014 & $* * *$ & NS \\
\hline weight change & 0.574 & 0.649 & 0.628 & 0.662 & 0.036 & NS & NS \\
\hline $\mathrm{NE} / \mathrm{DE}^{4}$ & 0.510 & 0.543 & 0.539 & 0.562 & 0.018 & NS & NS \\
\hline
\end{tabular}

I DOM= digestible organic matter.

$2 \mathrm{DE}=$ digestible energy.

3 Allowing $28 \mathrm{MJ}$ for each $\mathrm{kg}$ lost and subtracting $34 \mathrm{MJ}$ for each $\mathrm{kg}$ gained.

${ }_{4} \mathrm{NE}=$ net energy for milk, live weight gain $(20 \mathrm{MJ} / \mathrm{kg})$ and maintenance $\left(0.3 \mathrm{MJ} / \mathrm{kg} \mathrm{W} \mathrm{W}^{0.75}\right)$.

For significance: see Table 3.

the milk yield of cows given grass silage based diets (CAstle et al. 1981, Mayne and Gordon 1984, Тномаs et al. 1986, Phipps et al. 1987, SLoAn et al. 1987). The effect of barley fibre on milk production has not been studied earlier, but feeding of a corresponding byproduct from the corn wet-milling industry, maize gluten feed, led to lower milk yield when it replaced maize and soybean meal in complete mixted diets (STAPLES et al. 1984, 
Macleod et al. 1985). The lower yield was attributable to the reduced feed intake. Replacing maize and soybean meal by maize gluten feed in dry form increased feed intake and thereby increased FCM yield (MACLEOD et al. 1985).

A tendency for lower milk fat content with increasing level of barley fibre agrees with the observations of Tномаs et al. (1986) and HuhtANEN (1987 a) for experiments where unmolassed sugar beet pulp based supplements was substituted for barley at the level of $420-440 \mathrm{~g} / \mathrm{kg}$ of the total DM intake, similar to the present study. Likewise CASTLE et al. (1975) reported a higher milk fat content in cows given barley supplements than in those given dried grass supplements with grass silage ad libitum. Higher milk fat content in cows given silage and barley may be related to a high proportion of butyrate in rumen VFA (Huhtanen 1987 b). Supplementation of silage diets with barley leads to a marked increase in the number of total protozoa in the rumen (CHAMBERLAin et al. 1985) which may explain the high proportion of butyrate in rumen VFA. In contrast to the present results, Staples et al. (1984) and Macleod et al. (1985) reported higher milk fat content with on maize gluten than on diets of maize.

Linear decrease in milk protein content as the proportion of barley fibre in the diet was increased agrees with the results of STAPLES et al. (1984) and MACLEOD et al. (1985). The reasons for the decrease are uncertain but three points need to be considered. First, there where differences in the intakes of supplement and RSM, too. However, the reduction in the intake of supplement was small, and in fact the total DM intake tended to be higher when diets BF and FB were given. Second, the digestibility of OM decreased with the level of barley fibre in the diet and consequently DE intake decreased. The reduction in DE intake was rather small when diets $\mathrm{BF}$ and $\mathrm{FB}$ were given and it is unlikely that differences in the intake of supplement or DE can explain the lower milk protein content totally.

The third point is the difference in fat con- tent of the supplements: the fat content of barley fibre was $41 \mathrm{~g} / \mathrm{kg}$ higher than that of barley. It is well recognised that increasing the fat content of dairy cow diets leads to a lower milk protein content (see Тномаs 1984). In a number of trials the energy source of the supplement was found not to affect milk protein content (CASTLE et al. 1981, MAYNE and GorDON 1984, Sloan et al. 1987, Huhtanen 1987 a). However, Тномаs et al. (1986) and PHIPPS et al. (1987) found a tendency for concentrates based on highly digestible fibre sources to decrease milk protein content. The lower milk protein content associated with the use of concentrate based on sugar beet pulp and rice bran (TномAs et al. 1986) may well have been due to inclusion of fat in the concentrate and not the digestible fibre per se. Also Thomas and RoBERTSON (1987) observed a large reduction in milk protein content when of $60 \mathrm{~g} \mathrm{fat} / \mathrm{kg}$ was included in concentrate containing a large proportion of fibrous byproducts.

The reduction in the digestibility of DM and $\mathrm{OM}$ with increasing level of barley fibre is similar to that reported by StAPLes et al. (1984) when the proportion of wet maize gluten feed in the diet was increased. On the other hand, when barley was replaced by sugar beet pulp (MAYNE and Gordon 1984, HuhtaNEN 1987 a) or starchy concentrate by fibrous concentrate (PHIPPs et al. 1987), no differences in OM digestibility were observed. OM digestibility of barley fibre calculated by difference was markedly lower in the present experiments than was found in sheep $(0.67 v$. 0.74) fed at the maintenance level (NÄsı 1988). The size of barley fibre particles is small and they were available for passage without further comminution. The small particle size is necessary for the starch process. Because the level of feed intake in dairy cows was 3-4 times higher than in sheep, digesta retention time is shorter (Growum and Williams 1977), with reduced digestibility. The lower digestibility of barley fibre in lactating dairy cows than in sheep is in agreement with results of Steg et al. (1985) and Sutton et al. (1987), 
who reported a greater reduction in the digestibility of diets based on fibrous by-products than of diets based on starchy supplements when the level of feeding was raised.

In contrast to the present results, Staples et al. (1984) found that digestibilities of NDF, $\mathrm{ADF}$ and especially hemicellulose were linearly increased by substitution of wet maize gluten feed for maize and soybean meal. This may indicate that the digestibilities of cell wall carbohydrates of maize gluten feed are higher than those of barley fibre. It seems unlikely that barley fibre reduced the digestibility of grass silage because silage intake was increased with increasing level of barley fibre. Rather, this argues that the cell wall components of barley fibre were less digestible than those of grass silage. As the proportion of barley fibre in the diet increased, the supplement contributed proportionately more to the intake of cell wall components.

The difference in ME intakes estimated from feed tables and based on digestibility measurements increased with the proportion of barley fibre in the diet. This can partly be attributed to the use of the same energy value for DOM (19 MJ $/ \mathrm{kg}$ DOM) for all diets irrespective of fat content and partly to the reduced digestibility of barley fibre at high level of intake in dairy cows. The value of 0.637 for the efficiency of utilization of ME for milk production when diet $\mathrm{F}$ was given is similar to values of MAFF (1975) and ARC (1980), suggesting that the cows were close to energy balance. On the other hand, lower values with higher levels of barley in the diet indicate either lower efficiency of ME utilization or, more likely, a change in energy parti- tioning. In a previous trial, plasma insulin concentration was significantly higher in cows given barley than in those given sugar beet pulp (MietTinen and HUHTANEN 1987, unpublished), which would be expected to increase the uptake of nutrient by adipose tissue while depressing lipolysis.

Subtracting ME requirements from ME intake gives the ME available for production $\left(\mathrm{ME}_{\mathrm{p}}\right)$, and the ME used for milk production was calculated as milk energy/ $k_{1}$ (a value of 0.62 was used for $k_{1}$, MAFF 1975). The difference between $\mathrm{ME}_{\mathrm{p}}$ and milk energy/ $\mathrm{k}_{1}$ was considered to be associated with body weight change. Estimates for body energy balance indicate that, as the proportion of barley fibre in the diet increased, the cows were storing less energy in the body. ME balance estimates were $17,10,7$ and $-3 \mathrm{MJ}$ for diets B, BF, FB and $\mathrm{F}$, respectively.

\section{Conclusions}

The productive value of barley fibre in lactating dairy cows given grass silage ad libitum was better compared with barley than could be estimated from digestibility values determined in sheep. Calculation of energy balance suggested that, relative to other diets, cows given barley partitioned more energy to adipose tissue and cows given increasing amounts barley fibre partitioned a greater proportion of the production energy to milk. Because the cows refused to eat all the supplement containing barley fibre alone, we do not recommend using this kind of barley fibre alone as energy supplement.

carbohydrate supplements on ruminal concentration of ammonia in animals given grass silage. J. agric. Sci., Camb. 104: 47-58.

CASTLE, M.E. 1982. Feeding high-quality silage. Silage for milk production. (Ed. Rook, J.A.F. \& Thomas, 
P.C.). Technical Bulletin 2. pp. 127-150. National Research Institute for Research in Dairying, Reading/Hannah Research Institute, Ayr.

—, M.E., Gill, M.S. \& Watson, J.N. 1981. Silage and milk production: a comparison between barley and dried sugarbeet pulp as silage supplements. Grass and Forage Science 36: 319-324.

- \& WATSON, J.N. 1975. Silage and milk production: a comparison between barley and dried grass as supplements to silage of high digestibility. J. Br. Grassl. Soc. 30: $217-222$.

Goering, H.R. \& Van Soest, P.J. 1970. Forage fiber analyses. Agriculture Handbook No. 379. United States Dept. of Agric. Washington.

Grovum, W.L. \& Willıams, V.J. 1977. Rate of passage of digesta in sheep. 6. The effect of level of food intake on matematical predictions of the kinetics of digesta in the reticulorumen and intestines. Br. J. Nutr. 30: 313-329.

Huhtanen, P. 1988. The effects of barley, unmolassed beet pulp and molasses supplements on organic matter, nitrogen and fibre digestion in the rumen of cattle given silage diet. Anim. Feed Sci. Technol. (In Press)

- 1987 a. The effect of dietary inclusion of barley, unmolassed sugar beet pulp and molasses on milk production, digestibility and digesta passage in dairy cows given silage based diet. J. agric. Sci Finl. 59: 101-119.

- $1987 \mathrm{~b}$. The effect of carbohydrate supplements on the utilization of grass silage diets. pp. 1-45. Academic Dissertation. Department of Animal Husbandry, University of Helsinki SF-00710 Helsinki.

Macleod, G.K., Droppo, T.E. Grieve, D.G., Barney, D.J. \& RAFAlowSKı, W. 1985. Feeding value of wet corn gluten feed for lactating dairy cows. Can. J. Anim. Sci. 65: 125: 134.

MAFF (Ministry of Agriculture, Fisheries and Food). 1975. Energy allowances and feeding systems for ruminants. Technical Bulletin 33. 79 p. London.

Mayne, C.S. \& Gordon, F.J. 1984. The effect of type of concentrate and level of concentrate feeding on milk production. Anim. Prod. 39: 65-76.

Miettinen, H. \& Huhtanen, P. 1987. The effect of the type of supplement on blood metabolites in dairy cows given grass silage ad libitum. Unpublished.

NAsı, M. 1988. Evaluating of barley feed fractions from integrated barley ethanol-starch process in diets of ruminants. J. agric. Sci Finl. 60: 701-709.

Phipps, R.H., Sutton, J.D., Weller, R.F. \& Bines, J.A. 1987. The effects of concentrate composition and method of silage feeding on intake and performance of lactating dairy cows. J. agric. Sci., Camb. 109: 337-343. Porter, M.G., Patterson, D.C., Steen, R.W. \& Gor-
DON, F.J. 1984. Determination of dry matter and gross energy of grass silage. Proc. 7th Silage Conf. Queens's Univ. Belfast. (Ed. Gordon, F.J. \& Unsworth, E.F). pp. 89-90.

Salo, M-L., Tuori, M. \& KiISKinen, T. 1982. Rehutaulukot ja ruokintanormit. 70 p. Helsinki.

Sloan, B.K. \& Rowlinson, P. 1987. A note on concentrate energy source for dairy cows in mid lactation. Anim. Prod. 45: 321-323.

Snedecor, G.W. \& Cochran, W.C. 1967. Statistical methods. 6th Ed. 593 p. The Iowa State Univ. Press. Ames, USA.

Staples, C.R., Davis, C.L., McCoy, G.C. \& Clark, J.H. 1984. Feeding value of wet corn gluten feed for lactating dairy cows. J. Dairy Sci. 67: 1214-1220.

Steg, A., Honig, Y. Van Der \& Visser, H. De. 1985. Effect of fibre in compound feed on the performance of ruminants. Recent Advances in Animal Nutrition. (Ed. Haresign, W. \& Cole, D.J.A.) pp. 113-129. Butterworths.

Sutton, J.D., Bınes, J.A., Morant, S.V., Napper, D.J. \& GiVens, D.I. 1987. A comparison of starchy and fibrous concentrates for milk production, energy utilization and hay intake by Friesian cows. J. agric. Sci., Camb. 109: 375-386.

Thomas, C., Aston, K., Daley, S.R. \& Bass, J. 1986. Milk production from silage. 4 . The effect of the composition of the supplement. Anim. Prod. 42: 315-325.

Tномаs, P.C. 1984. Feeding and milk protein production. In Milk Compositional quality and its Importance in Future Markets (Ed. Castle, M.E. \& Gunn, R.G.), Occ. Publ. Br. Soc. Anim. Prod, No. 9. Pp. 53-67.

Thomas, P.C. \& Robertson, S. 1987. The effect of lipid and fibre source and content on silage intake, milk production and energy utilization. In Eighth Silage Conference, Summary of Papers. Sept. 1987. pp. 173-174.

- \& Chamberlain, D.G. 1982. Silage as a foodstuff. In Silage for Milk Production (Ed. Rook, J.A.F. \& Thomas, P.C.) pp. 63-101. National Research Institute for Research in Dairying. Reading/Hannah Research Institute, Ayr.

Tilley, J.M.A. \& Terry, R.A. 1963. A two-stage technique for in vitro digestion of forage crops. $\mathrm{J}$. Br. Grassl. Soc. Society 18: 104-111.

Tyrrel, H.F. \& Reid, J.T. 1965. Prediction of energy value of cow's milk. J. Dairy Sci. 48: 1215-1223.

Van Keulen, J. \& Young, B.A. 1977. Evaluation of acidinsoluble ash as a natural marker for digestibility studies. J. Anim. Sci. 44: 282-287.

Ms received 


\section{Ohran ja integroidusta tärkkelys- etanoliprosessista saatavan ohrarehun vaikutus säilörehun syöntiin ja maidontuotantoon}

\author{
Pekka Huhtanen, Hannele Ala-Seppälä ja \\ Matti Näsi \\ Helsingin yliopisto, kotieläintieteen laitos, \\ $00710 \mathrm{Helsin} k i$
}

Tutkimuksessa verrattiin ohran ja integroidusta tärkkelys-etanoliprosessista saatavan ohrarehun (120 g raakavalkuaista, 550 neutraalidetergenttikuitua, $120 \mathrm{~g}$ tärkkelystä/kg kuiva-ainetta (ka)) vaikutusta säilörehun syöntiin, maidontuotantoon ja rehun sulavuuteen lypsylehmillă. Koe-eläimină oli $8 \mathrm{Ay}$-lehmảă, joista puolet oli ensikkoja. Koe tehtiin kaksinkertaisena $4 \times 4$ latinalaisena neliônă. Perusvăkirehuna oli ohra (A), josta 1/3 (B), 2/3 (C) tai 3/3 (D) korvattiin ohrarehulla. Năită rehuja annettiin $6.5 \mathrm{~kg} \mathrm{ka} / \mathrm{pv}$, minkä lisăksi lehmăt saivat $1 \mathrm{~kg}: \mathrm{n}$ rypsirouhetta ja $0.25 \mathrm{~kg}$ kivennäisseosta päivăssă. Săilörehua oli vapaasti saatavilla 24 tuntia vuorokaudessa.

Ohrarehun osuuden lisaaăntyessä säilörehun kuiva-aineen syönti lisääntyi $9.91 \mathrm{~kg}: \mathrm{sta} 11.56 \mathrm{~kg}: \mathrm{aan} / \mathrm{pv}$ $(\mathrm{P}<0.001)$. Ohrarehun huonomman maittavuuden vuoksi lehmăt sỏivăt runsaasti ohrarehua sisăltäviả väkirehuja (C; D) văhemmăn kuin pelkkaaă ohraa, joten erot kuivaaineen syönnissă yhteensă olivat pienempiä eivătkă olleet tilastollisesti merkitseviä. Ruokinnoilla $\mathrm{B}$ ja $\mathrm{C}$ kuiva-aineen syönti oli keskimäărin $0.73 \mathrm{~kg}(\mathrm{P}<0.1)$ suurempi kuin pelkkaaă ohraa saaneilla lehmillă.
Ohrarehun osuudella ei ollut merkitsevaaaa vaikutusta maitotuotokseen (keskimäärin 24.6 kg/pv) eikä rasvakorjattuun maitotuotokseen. Maidon valkuaispitoisuus aleni merkitsevästi $(\mathrm{P}<0.01)$ ohrarehun osuuden lisaaăntyessä ja sama suuntaus $(\mathrm{P}<0.1)$ oli todettavissa myös rasvapitoisuuden osalta.

Văkirehun muuttuessa pelkăstä ohrasta pelkkaaaan ohrarehuun maitovalkuaisen tuotanto văheni $5.2 \%$ $(\mathrm{P}<0.05)$.

Ohrarehun sulavuus oli huonompi kuin ohran ja dieetin orgaanisen aineen sulavuus laski 0.742 :sta 0.661 :een $(\mathrm{P}<0.001)$ lisăttăessä ohrarehun osuus 0:sta $100 \%$ :iin văkirehussa. Raakavalkuaisen ja raakarasvan sulavuuteen ohrarehulla ei ollut vaikutusta, mutta solunseinămäaineiden sulavuus huononi ohrarehun osuuden lisảäntyessả. Laskelmat energian hyväksikảytőstă osoittavat, ettă ohran muuntokelpoisen energian hyväksikäyttö maidontuotantoon oli huonompi kuin ohrarehun tai todennäköisemmin, ohraa saaneet lehmăt käyttivăt suuremman osan energiasta kudosvarastojen kasvattamiseen maidontuotannon sijasta kuin ohrarehua saaneet. 